\title{
Formation Mechanism and Influence Factors of Roll Surface Oil Film Thickness in the Double Cold Reduction Mill
}

\author{
Cheng Qian, ${ }^{1,2}$ Zhenhua Bai $\mathbb{D}^{2,3}$ Jiasheng Zhang, ${ }^{2}$ Yaya Cui, ${ }^{2}$ and Changchun Hua ${ }^{1}$ \\ ${ }^{1}$ Institute of Electrical Engineering, Yanshan University, Qinhuangdao, Hebei 066004, China \\ ${ }^{2}$ National Engineering Research Center for Equipment and Technology of Cold Strip Rolling, Yanshan University, Qinhuangdao, \\ Hebei 066004, China \\ ${ }^{3}$ State Key Laboratory of Metastable Materials Science and Technology, Yanshan University, Qinhuangdao, Hebei 066004, China \\ Correspondence should be addressed to Zhenhua Bai; bai_zhenhua@aliyun.com
}

Received 26 November 2019; Revised 17 April 2020; Accepted 23 April 2020; Published 21 May 2020

Academic Editor: Mijia Yang

Copyright (C) 2020 Cheng Qian et al. This is an open access article distributed under the Creative Commons Attribution License, which permits unrestricted use, distribution, and reproduction in any medium, provided the original work is properly cited.

\begin{abstract}
In the double cold rolling process, the emulsion entering the roll gap during the double cold rolling process has the characteristics of high concentration and small flow rate so that the roll surface oil film thickness will affect roll gap oil film thickness, which in turn affects the rolling friction coefficient. This paper analyzes the formation mechanism and evolution process of the roll surface oil film thickness by considering the equipment and process characteristics of the emulsion direct injection application lubrication system. Then, based on the principle of fluid dynamics, the roll surface oil film thickness model in the double cold rolling process is established, and the prediction of the roll surface oil film thickness during the double cold rolling process is realized. Subsequently, the effects of five factors, such as rolling speed, work roll roughness, maximum contact stress between rolls, emulsion initial dynamic viscosity, and emulsion pressure viscosity coefficient, on the roll surface oil film thickness are quantitatively analyzed, and the corresponding influence laws are given. Finally, the relevant model and software that are applied to the 1220 double cold reduction mill have achieved good results.
\end{abstract}

\section{Introduction}

Double cold reduction refers to a further thinning production process of strip after the annealing process. The strip can have the characteristics of thin thickness, high strength, high hardness, good surface, and shape quality through the double cold rolling process. It is widely used in the industries of can making, packaging, and electronics [1,2]. In order to reduce the rolling pressure and rolling power and improve the surface quality of the strip, the double cold rolling process uses the emulsion direct injection application lubrication system to lubricate the strip. Considering that the emulsion sprayed on the surface of strip can precipitate a certain thickness of oil film before entering the roll gap and the emulsion has the characteristics of high concentration and low flow rate, the influence of the roll surface oil film thickness on oil film thickness in the rolling deformation zone cannot be neglected.
Many scholars have studied the oil film thickness model of strip rolling process. Wilson and Murch [3] analyzed the formation mechanism of lubricating oil film in the rolling deformation zone under the liquid lubrication condition and derived the calculation model of oil film thickness at the entry of rolling deformation zone. Azushima et al. $[4,5]$ proposed a numerical calculation method based on the new starvation model and calculated the entry oil film thickness by changing the friction factor. Fu et al. [6,7] applied the fluid dynamics principle, based on the surface topography of the strip, to establish the unstable oil film model of the rolling inlet zone, and the nonlinear relationship between the inlet angle, the reduction, and the thickness of the entry strip and the thickness of the inlet film was analyzed. Based on the theory of fluid dynamics and plastic deformation, Sun et al. [8] established the cold rolling lubricant oil thickness model to predict and analyze the oil film thickness in the rolling deformation zone. It was concluded that the increase 
in the viscosity of the rolling oil or the decrease in the amount of reduction would cause the increase in the thickness of the oil film through experiments. Chen and $\mathrm{Li}$ [9] carried out the stainless steel cold rolling lubrication experiment and established mathematical model of oil film thickness in the deformation zone by regression fitting of experimental data. Wang and $\mathrm{Li}[10]$ used the unsteady lubrication theory to establish an unsteady rolling interface dynamic model. Chen et al. [11] studied the influence of oil film thickness variation on the accuracy of steel plate thickness and put forward a mathematical model of oil film thickness suitable for field application. Cui et al. [12] established the oil film thickness models for the upper and lower surfaces of the strip in the rolling deformation zone during the double cold rolling. On the basis of introducing the concept of emulsion concentration and emulsion flow rate, Li et al. [13] established the prerolling strip surface oil film thickness model for emulsion direct injection application lubrication system in the double cold reduction mill. It can be seen from the analysis that the above literature mainly studied the thickness of the rolling lubricating oil film with the cold rolling cycle lubrication system, while the research on the double cold rolling emulsion direct injection lubrication system is mainly focused on the roll gap deformation zone and the prerolling strip surface oil film. However, there is no study on the thickness of oil film on the roll surface during the double cold rolling process. By considering the equipment and process characteristics of emulsion direct injection application lubrication system, a model of roll surface oil film thickness during double cold rolling is established in this paper, and the influencing factors of the roll surface oil film thickness are analyzed.

\section{Roll Surface Oil Film Formation and Evolution Mechanism during the Double Cold Rolling Process}

The formation and evolution of the roll surface oil film thickness during the double cold rolling process are shown in Figure 1. The emulsion is sprayed on the strip surface at a certain distance from the roll gap. Before the strip enters the roll gap, the emulsion deposits a certain thickness of lubricating oil film on the strip surface. Oil film in the front of the rolling zone is formed by the superposition of the work roll surface oil film on the entry side of the mill and the oil film precipitated from emulsion sprayed on the strip surface.

In the wedge-shaped zone formed between the strip and the work roll, the oil film pressure rises and the thickness of the oil film decreases. When the oil film pressure reaches the plastic deformation value, the strip begins to undergo plastic deformation, and the oil film enters the rolling deformation zone, forming the entry oil film of the rolling deformation zone. In the rolling deformation zone, the oil film thickness decreases gradually with the decrease of strip thickness. Finally, the oil film at the exit of the rolling deformation zone is formed and distributed to the surface of the exit strip and the work roll in a certain proportion. With the rotation of the roll, the oil film on the surface of the work roll at the exit side

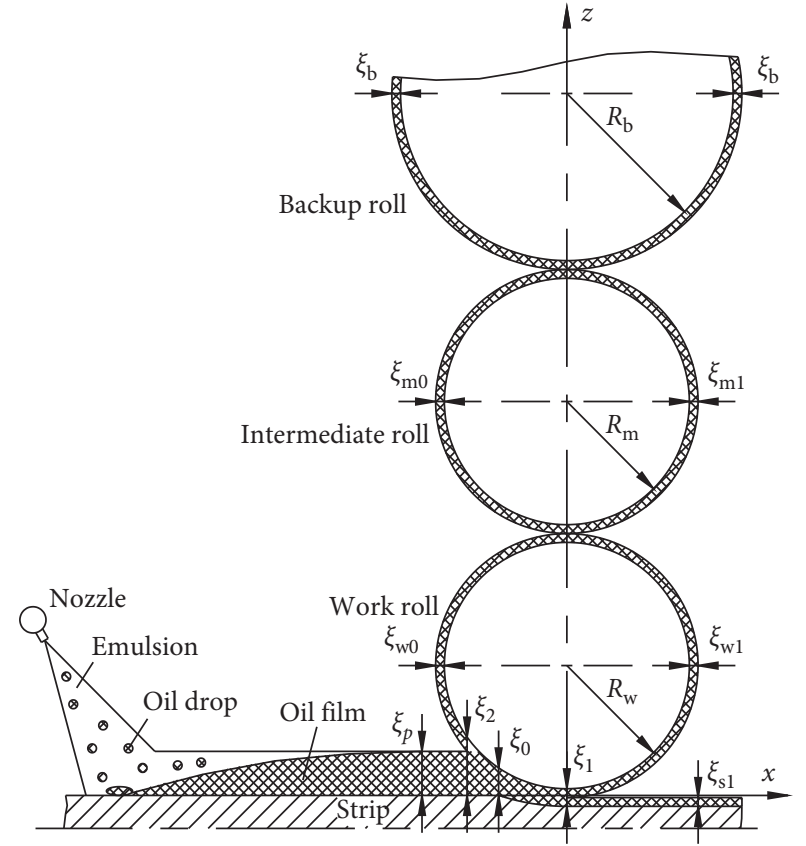

FIgURE 1: Schematic diagram of roll surface oil film thickness formation and evolution in the double cold rolling.

of the mill merges with the oil film on the surface of the intermediate roll at the exit side of the mill to form the oil film thickness between work roll and intermediate roll on the exit side of the mill.

In the roll gap contact zone between work roll and intermediate roll, the oil film thickness between work roll and intermediate roll gradually thinned, forming the oil film thickness between work roll and intermediate roll at the entry side of the mill and distributing the surface of the work roll and the intermediate roll at the entry side of the mill in a certain proportion. With the rotation of the intermediate roll and the backup roll, the oil film on the surface of the intermediate roll on the entry side of the rolling mill merges with the oil film on the surface of the backup roll to form the oil film between intermediate roll and backup roll at the entry side of the mill. In the gap contact zone between intermediate roll and backup roll, the oil film thickness between intermediate roll and backup roll gradually decreases, forming the oil film between intermediate roll and backup roll at the exit side of the mill and distributing it to the surface of the intermediate roll and the backup roll at the exit side of the mill in a certain proportion.

\section{Calculation Model of Roll Surface Oil Film Thickness in the Double Cold Rolling Process}

According to the principle of hydrodynamics [14], the Reynolds equation of lubricant film flow in the prerolling zone can be expressed in the following equation:

$$
\frac{\mathrm{d} p}{\mathrm{~d} \xi}=-\frac{6 \eta_{0} e^{\theta p}}{\alpha} \frac{\left(v_{0}+v_{\mathrm{r}}\right)}{60} \frac{\left(\xi-\xi_{0}\right)}{\xi^{3}},
$$


where $p$ is the oil film pressure at any position in the prerolling zone, $\xi$ is the oil film thickness at any position in the prerolling zone, $\xi_{0}$ is the oil film thickness in rolling deformation zone, $\eta_{0}$ is the dynamic viscosity of emulsion, $\theta$ is the hydraulic viscosity coefficient of emulsion, $\alpha$ is the bite angle, $v_{0}$ is the entry rolling speed, and $v_{\mathrm{r}}$ is the roll linear speed.

The oil film thickness in the front of the rolling zone is formed by the superposition of the work roll surface oil film at the entry side of the mill and the oil film deposited on the surface of the strip; therefore, the oil film thickness in the front entry of rolling can be obtained by the following equation:

$$
\xi_{2}=\xi_{p}+\xi_{\mathrm{w} 0}
$$

where $\xi_{p}$ is the oil film deposited on the surface of the strip and $\xi_{\mathrm{w} 0}$ is the work roll surface oil film thickness at the entry side of the mill.

The boundary conditions between the entry and exit oil film pressure and the oil film thickness in the prerolling zone can be expressed in the following equation:

$$
\left\{\begin{array}{l}
\left.\xi\right|_{p=0}=\xi_{2}, \\
\left.\xi\right|_{p=K_{0}-\sigma_{0}}=\xi_{0} .
\end{array}\right.
$$

By the definite integral of equation (1) with the boundary conditions of equation (3), the oil film thickness at the entry of deformation zone can be expressed in the following equation:

$$
\xi_{0}=\left(\sqrt{\frac{5 \alpha\left[1-e^{-\theta\left(K_{0}-\sigma_{0}\right)}\right]}{\theta \eta_{0}\left(v_{0}+v_{\mathrm{r}}\right)} \xi_{2}^{2}+\xi_{2}}-\sqrt{\frac{5 \alpha\left[1-e^{-\theta\left(K_{0}-\sigma_{0}\right)}\right]}{\theta \eta_{0}\left(v_{0}+v_{\mathrm{r}}\right)}} \xi_{2}\right)^{2},
$$

where $K_{0}$ is the entry deformation resistance of the strip and $\sigma_{0}$ is the entry tension of the strip.

Based on the incompressibility of the lubricating oil film in the rolling deformation zone, the thickness of the oil film at the exit of the rolling deformation zone can be expressed in the following equation:

$$
\xi_{1}=\frac{v_{0}+v_{\mathrm{r}}}{v_{1}+v_{\mathrm{r}}} \xi_{0}
$$

where $v_{1}$ is exit rolling speed.

According to Hertz elastic contact theory [15], the halfwidth of contact zone between work roll and intermediate roll and the half-width of contact zone between intermediate roll and backup roll can be obtained by the following equation:

$$
\left\{\begin{array}{l}
b_{\mathrm{mw}}=\sqrt{\frac{4}{\pi} \cdot \frac{1000\left(P+2 S_{\mathrm{w}}\right)}{l_{\mathrm{mw}}}\left(\frac{1-v_{\mathrm{m}}^{2}}{E_{\mathrm{m}}}+\frac{1-v_{\mathrm{w}}^{2}}{E_{\mathrm{w}}}\right) \frac{R_{\mathrm{m}} R_{\mathrm{w}}}{R_{\mathrm{m}}+R_{\mathrm{w}}}}, \\
b_{\mathrm{mb}}=\sqrt{\frac{4}{\pi} \cdot \frac{1000\left(P+2 S_{\mathrm{w}}+2 S_{\mathrm{m}}\right)}{l_{\mathrm{mb}}}\left(\frac{1-v_{\mathrm{m}}^{2}}{E_{\mathrm{m}}}+\frac{1-v_{\mathrm{b}}^{2}}{E_{\mathrm{b}}}\right) \frac{R_{\mathrm{m}} R_{\mathrm{b}}}{R_{\mathrm{m}}+R_{\mathrm{b}}}},
\end{array}\right.
$$

where $b_{\mathrm{mw}}$ is the half-width of contact zone between work roll and intermediate roll, $b_{\mathrm{mb}}$ is the half-width of contact zone between intermediate roll and backup roll, $P$ is the rolling pressure, $S_{\mathrm{w}}$ is the work roll's bending force, $S_{\mathrm{m}}$ is the intermediate roll's bending force, $l_{\mathrm{mw}}$ is contact length of work roll and intermediate roll, $l_{\mathrm{mb}}$ is contact length of the intermediate roll and backup roll, $E_{\mathrm{w}}$ is the work roll's elastic modulus, $E_{\mathrm{m}}$ is the intermediate roll's elastic modulus, $E_{\mathrm{b}}$ is the backup roll's elastic modulus, $v_{\mathrm{w}}$ is the work roll's Poisson's ratio, $v_{\mathrm{m}}$ is the intermediate roll's Poisson's ratio, $v_{\mathrm{b}}$ is the backup roll's Poisson's ratio, $R_{\mathrm{w}}$ is the work roll's radius, $R_{\mathrm{m}}$ is the intermediate roll's radius, and $R_{\mathrm{b}}$ is the backup roll's radius.

The coordinate system is established in the range of the contact zone between the rolls. The midpoint of contact width is taken as the origin and the direction of contact width is $x$-axis. The contact stress between work roll and intermediate roll and the contact stress between intermediate roll and backup roll are distributed in a semielliptical shape, which can be expressed in the following equation:

$$
\left\{\begin{array}{l}
p_{\mathrm{mw}}=p_{\mathrm{mw} 0} \sqrt{\left(1-\frac{x^{2}}{b_{\mathrm{mw}}^{2}}\right)} \\
p_{\mathrm{mb}}=p_{\mathrm{mb} 0} \sqrt{\left(1-\frac{x^{2}}{b_{\mathrm{mb}}^{2}}\right)}
\end{array}\right.
$$

where $p_{\mathrm{mw}}$ is the contact stress between work roll and intermediate roll, $p_{\mathrm{mb}}$ is the contact stress between intermediate roll and backup roll, $p_{\mathrm{mw} 0}$ is the maximum contact stress between work roll and intermediate roll, and $p_{\mathrm{mb} 0}$ is the maximum contact stress between intermediate roll and backup roll.

The contact force between work roll and intermediate roll and the contact force between intermediate roll and backup roll are integrated along the contact width direction, respectively, and the maximum contact stress between work roll and intermediate roll and the maximum contact stress between intermediate roll and backup roll can be calculated by the following equation:

$$
\left\{\begin{array}{l}
p_{\mathrm{mw} 0}=\frac{2000\left(P+2 S_{\mathrm{w}}\right)}{\pi b_{\mathrm{mw}} l_{\mathrm{mw}}} \\
p_{\mathrm{mb} 0}=\frac{2000\left(P+2 S_{\mathrm{w}}+2 S_{\mathrm{m}}\right)}{\pi b_{\mathrm{mb}} l_{\mathrm{mb}}} .
\end{array}\right.
$$

Furthermore, the contact bite angle of the work roll and the intermediate roll and the contact bite angle of the intermediate roll and the backup roll can be approximately expressed in the following equation:

$$
\left\{\begin{array}{l}
\alpha_{\mathrm{mw}}=\frac{\left(R_{\mathrm{m}}+R_{\mathrm{w}}\right) b_{\mathrm{mw}}}{R_{\mathrm{m}} R_{\mathrm{w}}} \\
\alpha_{\mathrm{mb}}=\frac{\left(R_{\mathrm{m}}+R_{b}\right) b_{\mathrm{mb}}}{R_{\mathrm{m}} R_{\mathrm{b}}}
\end{array}\right.
$$


where $\alpha_{\mathrm{mw}}$ is the contact bite angle between work roll and intermediate roll and $\alpha_{\mathrm{mb}}$ is the contact bite angle of intermediate roll and backup roll.

At the exit of the rolling deformation zone, the oil film in the rolling deformation zone separates and attaches to the surface of strip and work roll, respectively. The oil film thickness on the surface of the strip at the exit of the rolling mill and the oil film thickness on the surface of the work roll can be expressed in the following equation:

$$
\left\{\begin{array}{l}
\xi_{\mathrm{w} 1}=\frac{R a_{\mathrm{w}}}{R a_{\mathrm{s}}+R a_{\mathrm{w}}} \xi_{1}, \\
\xi_{\mathrm{s} 1}=\frac{R a_{\mathrm{s}}}{R a_{\mathrm{s}}+R a_{\mathrm{w}}} \xi_{1},
\end{array}\right.
$$

where $\xi_{\mathrm{wl}}$ is the oil film thickness on the surface of work roll at the exit side of the mill, $\xi_{\mathrm{s} 1}$ is the oil film thickness on the strip at the exit side of the mill, $\xi_{1}$ is the oil film thickness at the exit of the rolling deformation zone, $R a_{\mathrm{w}}$ is the work roll surface roughness, and $R a_{s}$ is the strip surface roughness.
The oil film on the surface of the work roll at the exit side of the mill merges with the oil film on the surface of the intermediate roll at the exit side of the mill to form the oil film thickness between work roll and intermediate roll at the exit side of the mill, which can be expressed in the following equation:

$$
\xi_{\mathrm{mw1}}=\xi_{\mathrm{m} 1}+\xi_{\mathrm{wl} 1},
$$

where $\xi_{\mathrm{mwl}}$ is the oil film thickness between work roll and intermediate roll at the exit side of the mill and $\xi_{\mathrm{m} 1}$ is the oil film thickness of the intermediate roll at the exit side of the mill.

In the range of the contact width between the work roll and the intermediate roll, the oil film thickness between work roll and intermediate roll is gradually reduced with the rollers rotation, and the oil film pressure rises. When the contact pressure between work roll and intermediate roll is the largest, the oil film thickness is the thinnest. After passing through the contact zone between work roll and intermediate roll, the oil film thickness between work roll and intermediate roll at the entry side of the mill can be obtained by the following equation:

$$
\xi_{\mathrm{mw} 0}=\left(\sqrt{\frac{5 \alpha_{\mathrm{mw}}\left(1-e^{-\theta p_{\mathrm{mw} 0}}\right)}{2 \theta \eta_{0} v_{\mathrm{r}}} \xi_{\mathrm{mw} 1}^{2}+\xi_{\mathrm{mw} 1}}-\sqrt{\frac{5 \alpha_{\mathrm{mw}}\left(1-e^{\left.-\theta p_{\mathrm{mw} 0}\right)}\right.}{2 \theta \eta_{0} v_{\mathrm{r}}}} \xi_{\mathrm{mw} 1}\right)^{2}
$$

where $\xi_{\mathrm{mw} 0}$ is the oil film thickness between work roll and intermediate roll at the entry side of the mill.

At the entry side of the mill, the oil film between work roll and intermediate roll is separated and attached to the surface of the work roll and the intermediate roll, respectively. The oil film thickness of the work roll and the intermediate roll at the entry side of the mill can be expressed in the following equation:

$$
\left\{\begin{array}{l}
\xi_{\mathrm{w} 0}=\frac{R a_{\mathrm{w}}}{R a_{\mathrm{w}}+R a_{\mathrm{m}}} \xi_{\mathrm{m} \mathrm{w} 0} \\
\xi_{\mathrm{m} 0}=\frac{R a_{\mathrm{m}}}{R a_{\mathrm{w}}+R a_{\mathrm{m}}} \xi_{\mathrm{m} \mathrm{0} 0},
\end{array}\right.
$$

where $\xi_{\mathrm{w} 0}$ is the oil film thickness on the surface of the work roll at the entry of the mill, $\xi_{\mathrm{m} 0}$ is the oil film thickness on the surface of the intermediate roll at the entry of the mill, and $R a_{\mathrm{m}}$ is the intermediate roll surface roughness.

In the contact position between intermediate roll and backup roll at the entry side of the mill, the oil film on the surface of the intermediate roll at the entry side of the mill merges with the oil film on the surface of the backup roll at the entry side of the mill to form the oil film thickness between intermediate roll and backup roll at the entry side of the mill, which can be expressed in the following equation:

$$
\xi_{\mathrm{mb} 0}=\xi_{\mathrm{m} 0}+\xi_{\mathrm{b} 0},
$$

where $\xi_{\mathrm{mb} 0}$ is the oil film thickness between intermediate roll and backup roll at the entry side of the mill and $\xi_{\mathrm{b} 0}$ is the oil film thickness on the surface of the backup roll at the entry side of the mill.

In the range of the contact width between intermediate roll and backup roll, the oil film thickness between intermediate roll and backup roll is gradually reduced with the rollers rotation, and the oil film pressure rises. When the contact pressure between intermediate roll and backup roll is the largest, the oil film thickness is the thinnest. After passing through the contact area between intermediate roll and backup roll, the oil film thickness between intermediate roll and backup roll at the exit side of the mill can be obtained by the following equation:

$$
\xi_{\mathrm{mb} 1}=\left(\sqrt{\frac{5 \alpha_{\mathrm{mb}}\left(1-e^{-\theta p_{\mathrm{mb} 0}}\right)}{2 \theta \eta_{0} v_{\mathrm{r}}} \xi_{\mathrm{mb} 0}^{2}+\xi_{\mathrm{mb} 0}}-\sqrt{\frac{5 \alpha_{\mathrm{mb}}\left(1-e^{-\theta p_{\mathrm{mb} 0}}\right)}{2 \theta \eta_{0} v_{\mathrm{r}}}} \xi_{\mathrm{mb} 0}\right)^{2},
$$


where $\xi_{\mathrm{mbl}}$ is the oil film thickness between intermediate roll and backup roll at the exit side of the mill.

At the exit side of the mill, the oil film between intermediate roll and backup roll is separated and attached to the surface of the intermediate roll and backup roll, respectively. The oil film thickness on the intermediate roll and the backup roll at the exit side of the mill can be expressed in the following equation:

$$
\left\{\begin{array}{l}
\xi_{\mathrm{m} 1}=\frac{R a_{\mathrm{m}}}{R a_{\mathrm{m}}+R a_{\mathrm{b}}} \xi_{\mathrm{mb} 1}, \\
\xi_{\mathrm{b} 1}=\frac{R a_{\mathrm{b}}}{R a_{\mathrm{m}}+R a_{\mathrm{b}}} \xi_{\mathrm{mb} 1},
\end{array}\right.
$$

where $\xi_{\mathrm{m} 1}$ is the oil film thickness on the surface of the intermediate roll at the exit side of the mill, $\xi_{\mathrm{b} 1}$ is the oil film thickness on the surface of the backup roll at the exit side of the mill, and $R a_{\mathrm{b}}$ is the backup roll surface roughness.

The thickness of the oil film on the backup roll surface remains unchanged during the rotation of the backup roll from the exit side of the mill to the entry side of the mill. Therefore, the thickness of the oil film on the surface of the backup roll at the exit side of the mill is equal to the thickness of the oil film on the surface of the backup roll at the entry side of the mill, and the surface oil film thickness of the backup roll can be expressed in the following equation:

$$
\xi_{\mathrm{b}}=\xi_{\mathrm{b} 0}=\xi_{\mathrm{b} 1},
$$

where $\xi_{\mathrm{b}}$ is the surface oil film thickness of the backup roll.

In order to more clearly explain the establishment of oil film thickness model on the roll surface, the schematic diagram of the calculation model of the oil film thickness on the roll surface is shown in Figure 2.

\section{Analysis of the Influencing Factors of Roll Surface Oil Film Thickness}

In order to quantitatively analyze the influence of process parameters on the roll surface oil film thickness during the double cold rolling process, taking the work roll surface oil film thickness as an example, the typical product of DR8M grade in the 1220 double cold reduction mill is used to simulate the influences of rolling speed, roll surface roughness, maximum contact stress between rolls, emulsion initial dynamic viscosity, and emulsion pressure viscosity coefficient on the work roll surface oil film thickness under the different strengths. The roll equipment parameters of the 1220 double cold reduction mill are listed in Table 1, and the rolling parameters of the typical DR8M grade steel are listed in Table 2.

Figure 3 shows the relationship between the work roll surface oil film thickness and rolling speed under the different strip strengths. It can be seen that the oil film thickness on the surface of work roll increases first and then decreases with the increase of rolling speed, when the strip strength remains unchanged. In the low rolling speed section, the volume of emulsion involved in the work roll increases with the increase of rolling speed, which leads to the increase of oil film thickness on the surface of the work roll. With the further increase of rolling speed, because the double cold rolling mill adopts the emulsion direct injection system, too fast rolling speed is not conducive to the precipitation of oil film in the emulsion, which ultimately leads to the downward trend of the work roll surface oil film thickness. When the rolling speed remains unchanged, the greater the strength of the strip, the smaller the oil film thickness on the surface of the work roll. On the contrary, the smaller yield strength of the strip, the greater the oil film thickness on the surface of the work roll.

Figure 4 shows the relationship between the work roll surface oil film thickness and the work roll roughness under the different strip strengths. It can be seen that the oil film thickness on the surface of work roll increases with the increase of the work roll roughness, when the strength remains unchanged. Because the roughness of the work roll increases, more oil film will be adsorbed on the surface of the work roll, which will increase the thickness of the oil film on the surface of the work roll. When the work roll roughness remains unchanged, the greater the strength of the strip, the smaller the oil film thickness on the surface of the work roll. On the contrary, the smaller the yield strength of the strip, the greater the work roll surface oil film thickness.

Figure 5 shows the relationship between the work roll surface oil film thickness and the maximum contact stress between work roll and intermediate roll under the different strip strengths. It can be seen that the oil film thickness on the surface of work roll decreases with the increase of maximum contact stress between work roll and intermediate roll, when the strip strength is constant. The maximum contact stress between work roll and intermediate roll becomes larger, so that more oil film attached to the work roll surface is extruded. Therefore, the thickness of the oil film on the surface of the work roll decreases. When the maximum contact stress between work roll and intermediate roll is constant, the greater the strength of the strip, the smaller the thickness of the oil film on the surface of the work roll. Conversely, the smaller yield strength of the strip, the greater the work roll surface oil film thickness.

Figure 6 shows the relationship between the work roll surface oil film thickness and the emulsion initial dynamic viscosity under the different strip strengths. It can be seen that the oil film thickness on the surface of work roll increases with the increase of the emulsion initial dynamic viscosity, when the strip strength is constant. With the increase of the initial dynamic viscosity of the emulsion, more oil film is introduced into the rolling deformation zone, which makes the thickness of oil film on the surface of the work roll increase. When the emulsion initial dynamic viscosity is constant, the greater the strength of the strip, the smaller the oil film thickness on the surface of the work roll. On the contrary, the smaller the strength of the strip, the greater the work roll surface oil film thickness.

Figure 7 shows the relationship between the work roll surface oil film thickness and the emulsion pressure viscosity coefficient under the different strip strengths. It can be seen 


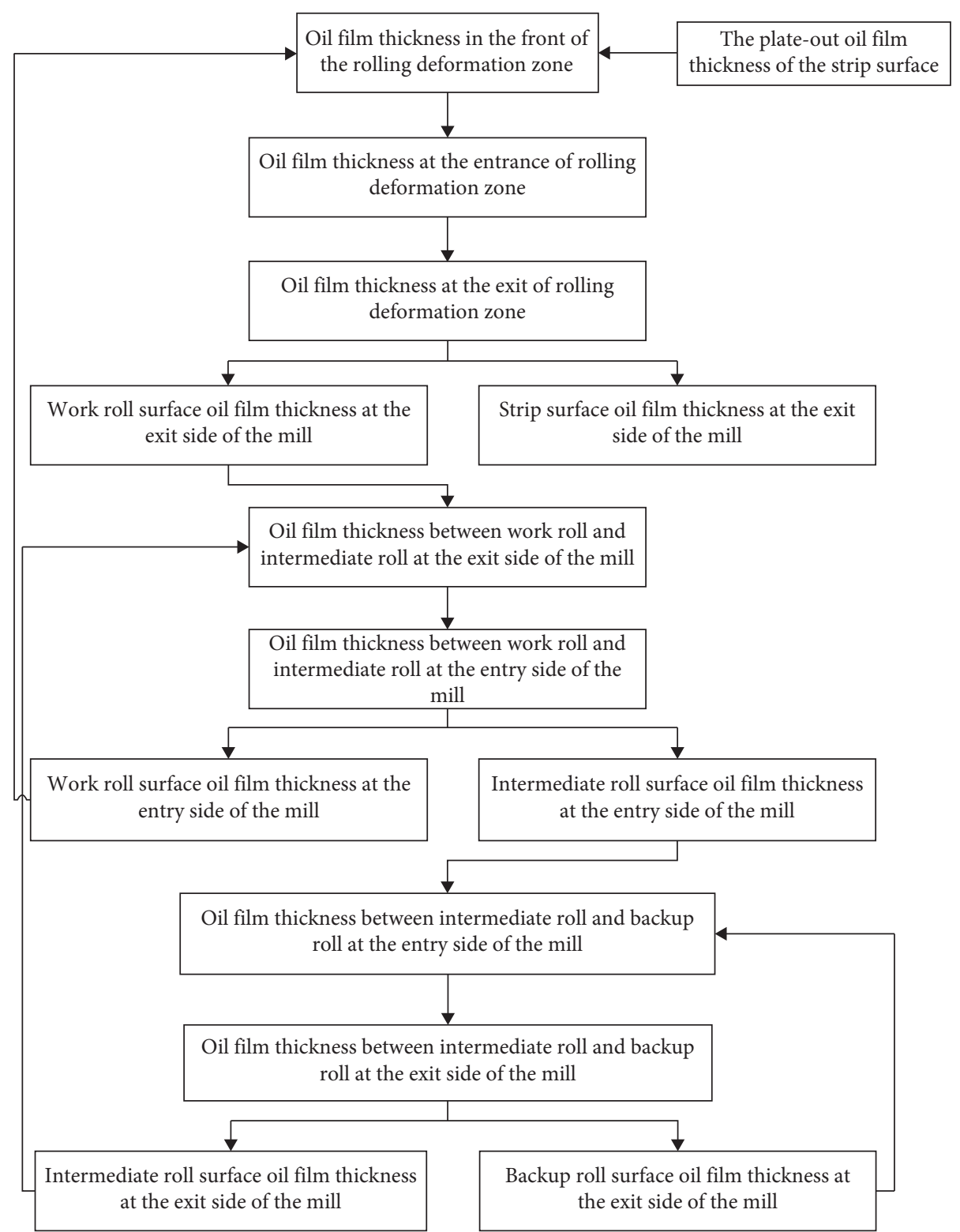

Figure 2: The schematic diagram of the calculation model of the oil film thickness on the roll surface.

that the oil film thickness on the surface of work roll increases with the increase of the emulsion pressure viscosity coefficient, when the strip strength is constant. With the increase of emulsion pressure viscosity coefficient, more oil film is introduced into the rolling deformation zone. Therefore, the thickness of oil film on the surface of work roll increases. When the emulsion pressure viscosity is constant, the greater the strength of the strip, the smaller the oil film thickness on the surface of the work roll. On the contrary, the smaller the strength of the strip, the greater the work roll surface oil film thickness.

\section{Field Application}

The 1220 double cold rolling mill adopts the emulsion direct injection lubrication system for rolling lubrication. The
TABLE 1: Roll equipment parameters of the 1220 double cold reduction mill.

\begin{tabular}{lc}
\hline Parameters & Numerical value \\
\hline Work roll radius $(\mathrm{mm})$ & 165 \\
Intermediate roll radius $(\mathrm{mm})$ & 240 \\
Backup roll radius $(\mathrm{mm})$ & 560 \\
Work roll length $(\mathrm{mm})$ & 1200 \\
Intermediate roll length $(\mathrm{mm})$ & 1200 \\
Backup roll length $(\mathrm{mm})$ & 1200 \\
\hline
\end{tabular}

friction coefficient of the roll gap is affected by the thickness of the oil film on the surface of the roll, which makes the strip rolling process unstable. At present, the oil film thickness on the surface of the roll can be measured offline only, and the oil film thickness on the roll surface cannot be obtained 
TABLE 2: Typical specification product parameters of the 1220 double cold reduction mill.

\begin{tabular}{lc}
\hline Parameters & Numerical value \\
\hline Strip width $(\mathrm{mm})$ & 850 \\
Entry strip thickness $(\mathrm{mm})$ & 0.210 \\
Exit strip thickness $(\mathrm{mm})$ & 0.145 \\
Rolling speed $(\mathrm{m} / \mathrm{min})$ & 720 \\
Work roll bending force $(\mathrm{kN})$ & 32 \\
Intermediate roll bending force $(\mathrm{kN})$ & 20 \\
Exit tension $(\mathrm{MPa})$ & 160 \\
Entry tension $(\mathrm{MPa})$ & 120 \\
Strip strength $(\mathrm{MPa})$ & 560 \\
Oil initial dynamic viscosity $(\mathrm{Pa} \cdot \mathrm{s})$ & 0.023 \\
Oil pressure viscosity coefficient $\left(\mathrm{MPa}^{-1}\right)$ & 0.012 \\
\hline
\end{tabular}

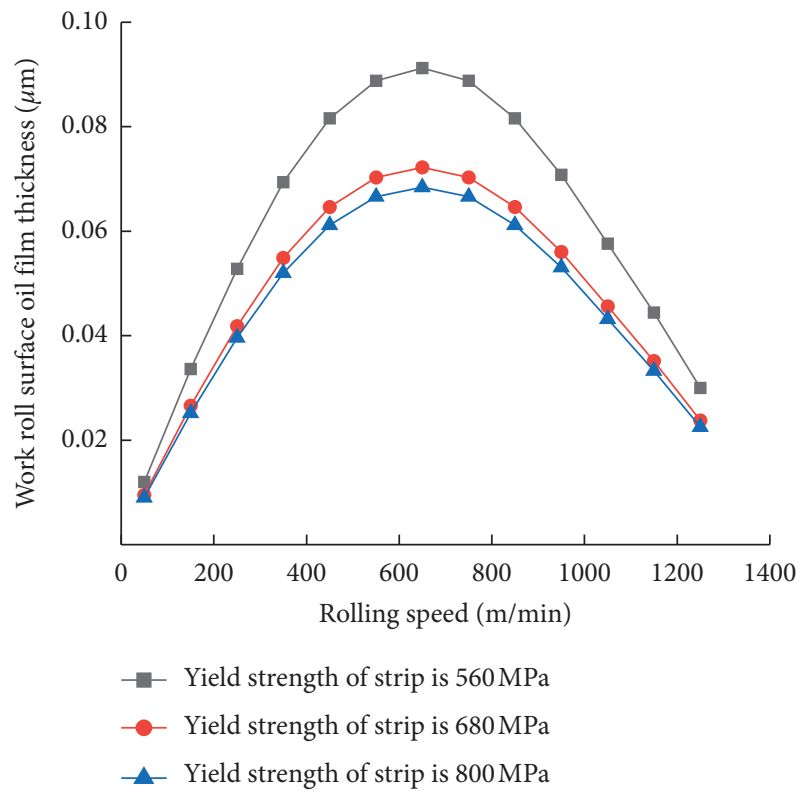

FIgURE 3: The relationship between work roll surface oil film thickness and rolling speed under the different yield strength of strip.

online. Therefore, the process control measures cannot be adopted to control the friction coefficient of the roll gap in time, which ultimately reduces the eligibility rate of the strip. According to the established roll surface oil film thickness calculation model, a software for calculating oil film thickness on roll surface is developed (Figure 8). The field operator inputs the relevant parameters and uses the software to calculate the oil film thickness on the roll surface, and the operator can better optimize the emulsion and rolling parameters.

In order to illustrate the accuracy of the roll surface oil film thickness calculation model established in this paper, four typical grades products of the 1220 double cold rolling mill are selected for testing. The rolling process parameters of products are shown in Table 3. Taking the oil film thickness on the surface of the work roll as an example, the oil film thickness of work roll surface is measured by weighing method. The weighing method is to cut the test piece from the rolled strip and weigh it accurately, followed by removing the lubricating oil on the test piece with solvent

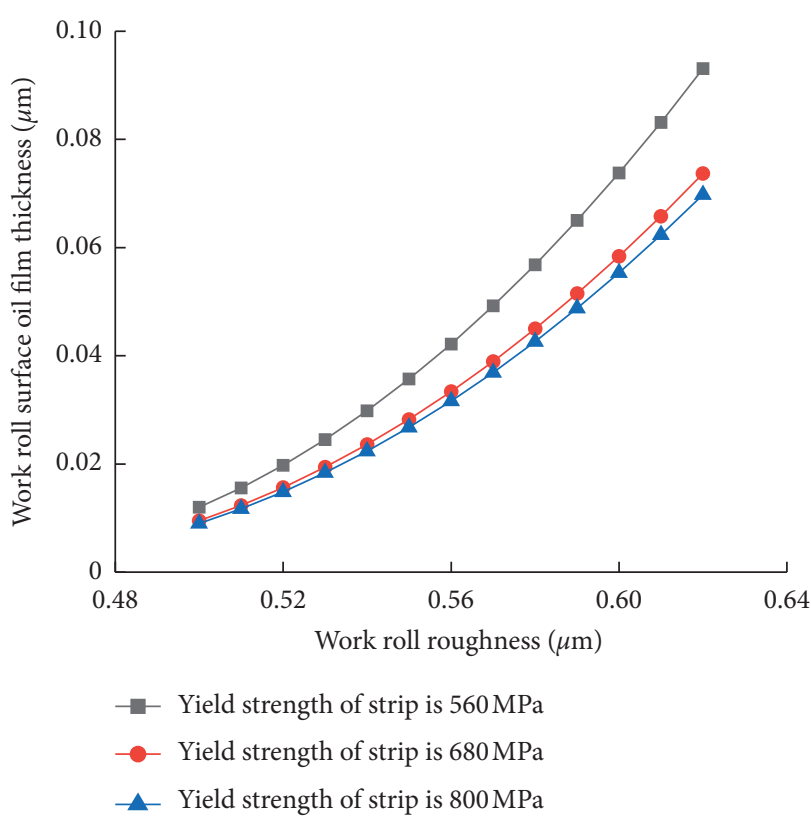

FIGURE 4: The relationship between work roll surface oil film thickness and roll roughness under the different yield strength of strip.

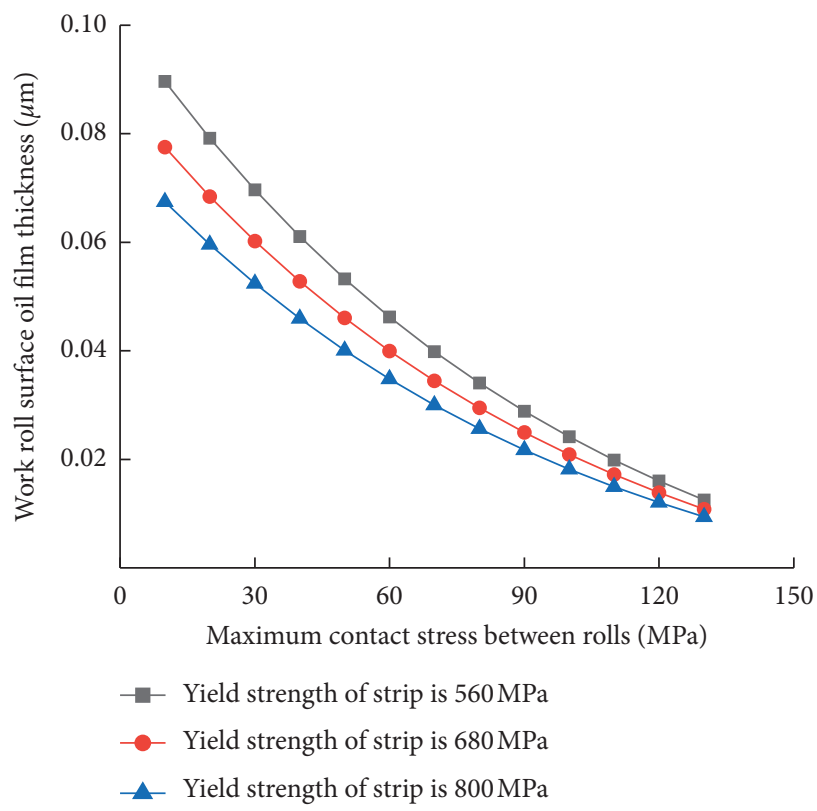

FIGURE 5: The relationship between the work roll surface oil film thickness and the maximum contact stress between rolls under the different yield strength of strip.

and weighing it again. The oil film mass of strip can be obtained by subtracting the weight of the two weighing processes, and then the oil film thickness on the surface of the rolling piece and the oil film thickness in the deformation zone can be obtained according to the mass formula. Finally, the thickness of the oil film on the surface of the roll can be calculated by the relationship between the roll and the strip roughness. The comparison between the oil film thickness on the work roll surface with the weighing method and the oil 


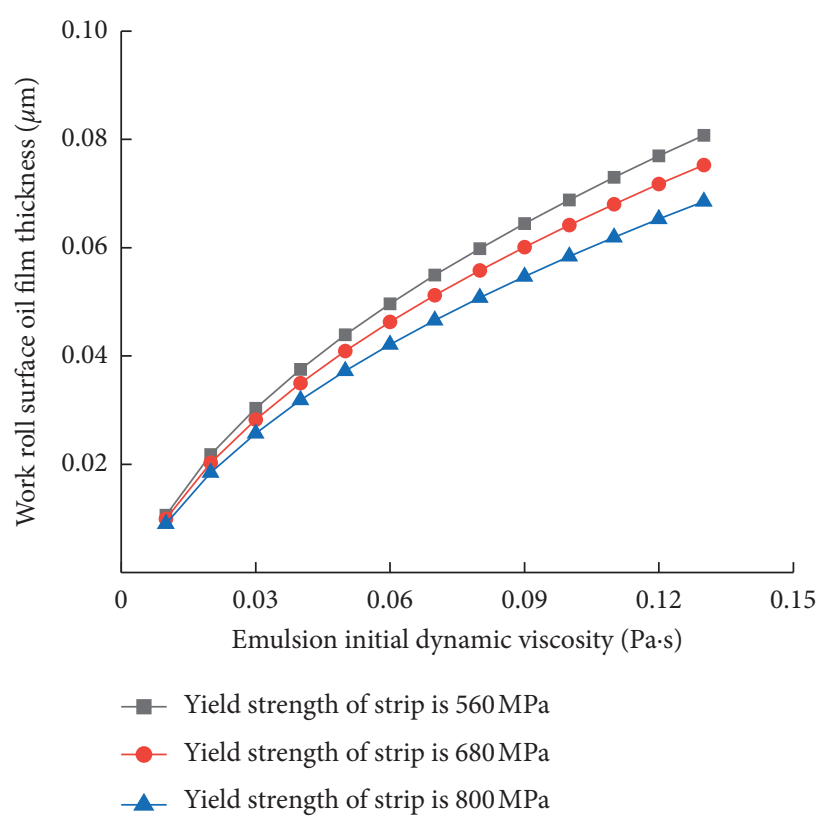

FIGURE 6: The relationship between the work roll surface oil film thickness and the emulsion initial dynamic viscosity under the different yield strength of strip.

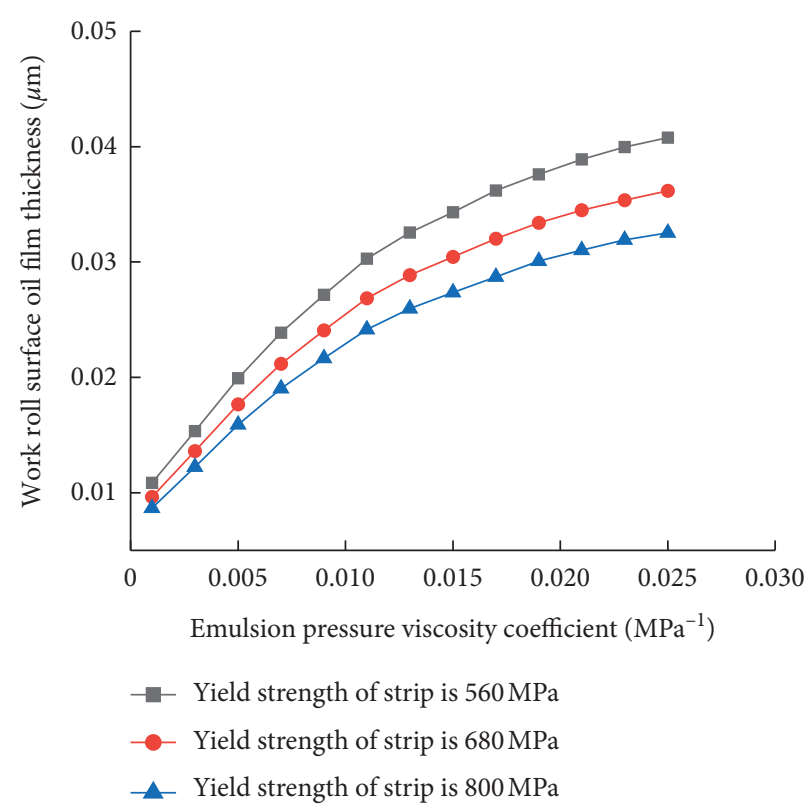

FiguRE 7: The relationship between the work roll surface oil film thickness and the emulsion pressure viscosity coefficient under the different yield strength of strip.

film thickness calculated by the model established in this paper is shown in Table 4.

It can be seen from Table 4 that when the product of DR7M grade is rolled, the measured value of the work roll surface oil film thickness at the exit side of the mill is $0.025 \mu \mathrm{m}$, and the calculated value of the model is $0.024 \mu \mathrm{m}$. The error is $4.0 \%$. The measured value of work roll surface oil film thickness at the entry side of the mill is $0.023 \mu \mathrm{m}$, and the calculated value of the model is $0.022 \mu \mathrm{m}$. The error is $4.35 \%$. When the product of DR8 grade in the double cold rolling mill is rolled, the measured value of the work roll surface oil film thickness at the exit side of the mill is $0.024 \mu \mathrm{m}$, and the calculated value of the model is $0.022 \mu \mathrm{m}$. The error is $8.33 \%$. The measured value of work roll surface oil film thickness at the entry side of the mill is $0.022 \mu \mathrm{m}$, and the calculated value of the model is $0.020 \mu \mathrm{m}$. The error is 


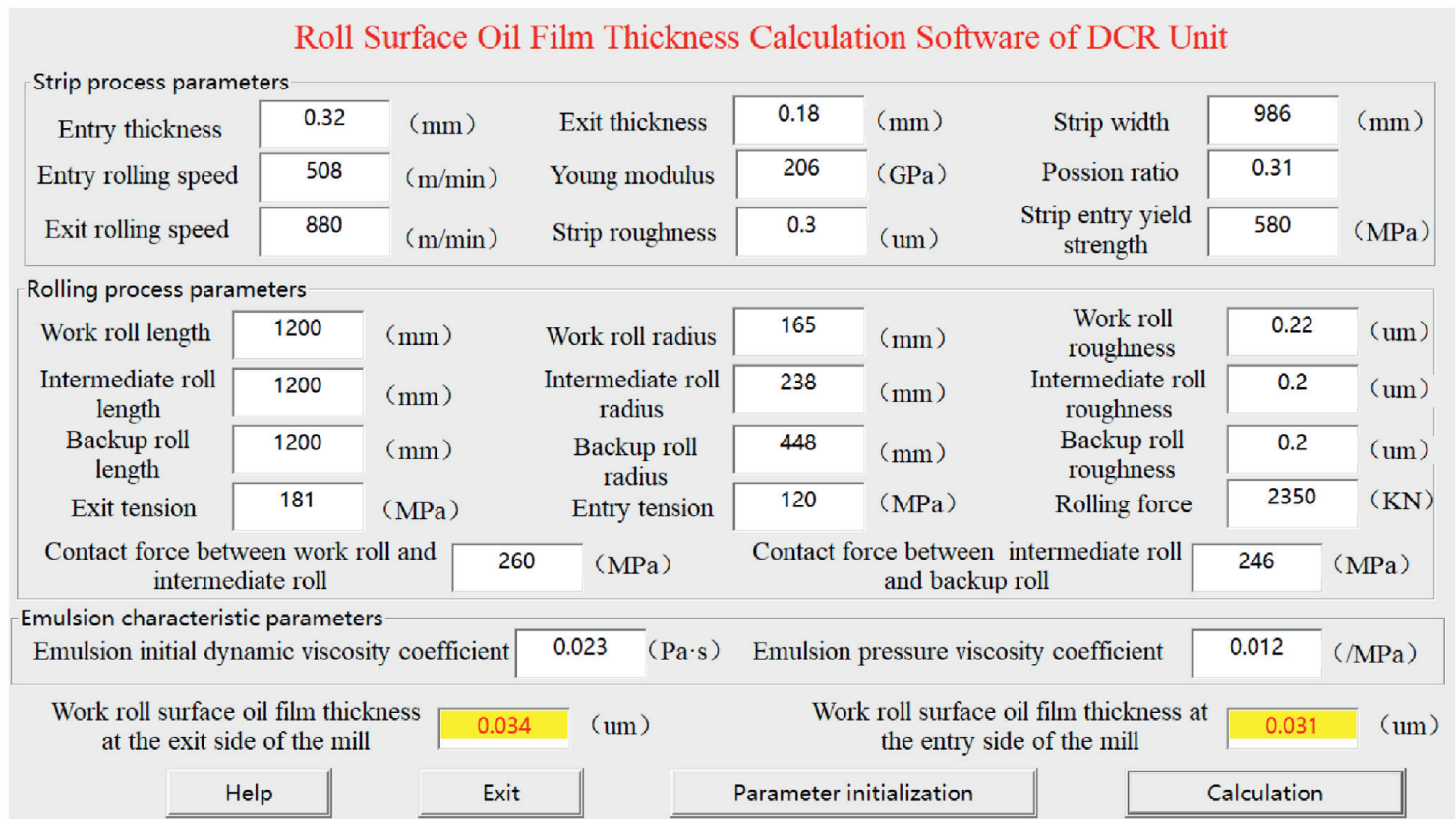

FIGURE 8: Roll surface oil film thickness calculation software.

TABLE 3: Rolling process parameters of typical strip products.

\begin{tabular}{|c|c|c|c|c|}
\hline \multirow{2}{*}{ Parameters } & \multicolumn{4}{|c|}{ Steel grade } \\
\hline & DR7M & DR8 & DR8M & DR9 \\
\hline Strip width (mm) & 926 & 921 & 968 & 952 \\
\hline Entry strip thickness $(\mathrm{mm})$ & 0.248 & 0.243 & 0.250 & 0.247 \\
\hline Exit strip thickness (mm) & 0.170 & 0.170 & 0.170 & 0.162 \\
\hline Rolling speed $(\mathrm{m} / \mathrm{min})$ & 687 & 653 & 686 & 805 \\
\hline Reduction rate $(\%)$ & 31 & 30 & 32 & 34 \\
\hline Rolling force $(\mathrm{kN})$ & 2620 & 2450 & 3020 & 4415 \\
\hline Exit tension $(\mathrm{MPa})$ & 168 & 155 & 181 & 190 \\
\hline Entry tension $(\mathrm{MPa})$ & 102 & 100 & 119 & 109 \\
\hline Deformation resistance $(\mathrm{MPa})$ & 560 & 550 & 580 & 620 \\
\hline
\end{tabular}

TABLE 4: Comparisons of measured and calculated work roll surface oil film thickness.

\begin{tabular}{|c|c|c|c|c|}
\hline \multirow{2}{*}{ Parameters } & \multicolumn{4}{|c|}{ Steel grade } \\
\hline & DR7M & DR8 & DR8M & DR9 \\
\hline \multicolumn{5}{|c|}{ Work roll surface oil film thickness at the exit side of the mill } \\
\hline Measured value $(\mu \mathrm{m})$ & 0.025 & 0.024 & 0.022 & 0.026 \\
\hline Calculated value $(\mu \mathrm{m})$ & 0.024 & 0.022 & 0.021 & 0.024 \\
\hline Error $(\%)$ & 4.00 & 8.33 & 4.55 & 7.69 \\
\hline \multicolumn{5}{|c|}{ Work roll surface oil film thickness at the entry side of the mill } \\
\hline Measured value $(\mu \mathrm{m})$ & 0.023 & 0.022 & 0.021 & 0.023 \\
\hline Calculated value $(\mu \mathrm{m})$ & 0.022 & 0.020 & 0.020 & 0.021 \\
\hline Error $(\%)$ & 4.35 & 9.09 & 4.76 & 8.69 \\
\hline
\end{tabular}

9.09\%. When the product of DR8M grade is rolled, the measured value of the work roll surface oil film thickness at the exit side of the mill is $0.022 \mu \mathrm{m}$, and the calculated value of the model is $0.021 \mu \mathrm{m}$. The error is $4.55 \%$. The measured value of work roll surface oil film thickness at the entry side of the mill is $0.021 \mu \mathrm{m}$, and the calculated value of the model is $0.020 \mu \mathrm{m}$. The error is $4.76 \%$. When the product of DR9 grade is rolled, the measured value of the work roll surface oil film thickness at the exit side of the mill is $0.026 \mu \mathrm{m}$, and the calculated value of the model is $0.024 \mu \mathrm{m}$. The error is 
$7.69 \%$. The measured value of work roll surface oil film thickness at the entry side of the mill is $0.023 \mu \mathrm{m}$, and the calculated value of the model is $0.021 \mu \mathrm{m}$. The error is $8.69 \%$. The measured and calculated values of the work roll surface oil film thickness at the entry and exit sides of the mill are all within $10 \%$, indicating that the calculation accuracy of the model meets the actual engineering requirements.

\section{Conclusions}

The formation and evolution mechanism of the roll surface oil film during the double cold rolling is described. The model of oil film thickness on the surface of rolls is established based on the Reynolds equation of lubrication flow and the hydrodynamic lubrication principle. Through the model, the roll surface oil film thickness during the double cold rolling can be predicted.

The influences of rolling speed, work roll roughness, maximum contact stress between work roll and intermediate roll, emulsion initial dynamic viscosity, and emulsion pressure viscosity coefficient on the work roll surface oil film thickness are analyzed. It is found that the work roll surface oil film thickness increases first and then decreases with the increase of rolling speed; the thickness of oil film on roll surface increases with the increase of roll roughness, emulsion initial dynamic viscosity, and emulsion pressure viscosity coefficient. The thickness of oil film on the roll surface decreases with the increase of maximum contact stress between work roll and intermediate roll.

Four typical products of the 1220 double cold rolling unit are selected for the verification and testing. It is found that the error values between the calculated work roll surface oil film thickness and the measured work roll surface oil film thickness at the entry and exit sides of the mill are less than $10 \%$, which can satisfy the practical engineering demand.

\section{Data Availability}

The data used to support the findings of this study are available from the corresponding author upon request.

\section{Disclosure}

A few experiments were made in Baosteel Cold Rolling Plant.

\section{Conflicts of Interest}

The authors declare that they have no conflicts of interest.

\section{Acknowledgments}

This work was supported by the Natural Science Foundation of Hebei Province under Grant no. E2016203385. The authors gratefully acknowledge the technical support of Baosteel.

\section{References}

[1] J. Ji, L. You, Y. F. Liu et al., "Development and application of skin pass and double cold-reduced mill processing for high quality ultra-thin uncoated thin-plated sheet," Steel Rolling, vol. 35, no. 1, pp. 49-51, 2018.

[2] X. J. Li, "Research on application of double cold reduction technology," Baosteel Technology, vol. 24, no. S1, pp. 61-63, 2006.

[3] W. R. D. Wilson and L. E. Murch, "A refined model for the hydrodynamic lubrication of strip rolling," Journal of $\mathrm{Lu}$ brication Technology, vol. 98, no. 3, pp. 426-431, 1976.

[4] A. Azushima and S. Inagaki, "Measurement and analysis of inlet oil film thickness in cold sheet rolling with oil-in-water emulsion," Tribology Transactions, vol. 52, no. 4, pp. 427-434, 2009.

[5] A. Azushima, S. Inagaki, and H. Ohta, "Plating out oil film thickness on roll and workpiece during cold rolling with $\mathrm{O} / \mathrm{W}$ emulsion," Tribology Transactions, vol. 54, no. 2, pp. 275-281, 2011.

[6] K. Fu, Y. Zang, Z. Gao, Q. Qin, and D. Wu, "Non-linear dynamics of inlet film thickness during unsteady rolling process," Chinese Journal of Mechanical Engineering, vol. 29, no. 3, pp. 522-530, 2016.

[7] K. Fu, Y. Zang, and Z. Y. Gao, "Unsteady lubrication film characteristics at rolling interface," Journal of Northeastern University (Natural Science), vol. 35, no. 9, pp. 1324-1328, 2014.

[8] J. L. Sun, Y. L. Kang, and J. Liu, "Characteristics of oil film formation on cold rolled strips," Journal of Iron and Steel Research, vol. 13, no. 1, pp. 10-13, 2001.

[9] J. S. Chen and C. S. Li, "Forecasting and controlling software of thermal scratch defect in cold rolling process," Journal of Northeastern University (Natural Science), vol. 35, no. 4, pp. 524-528, 2014.

[10] Q. Y. Wang and Z. H. Li, "Research on characteristics of oil film for work interface in metal rolling processes," China Mechanical Engineering, vol. 20, no. 15, pp. 1866-1869, 2009.

[11] J. H. Chen, Q. S. Zhang, B. Li et al., "Research on mathematical model of oil film gage on plate rolling mill," Iron and Steel, vol. 36, no. 11, pp. 42-45, 2001.

[12] Y. Y. Cui, Z. H. Bai, X. F. Li et al., "Oil film thickness model in deformation zones during double cold reduction mill," China Mechanical Engineering, vol. 30, no. 5, pp. 560-567, 2019.

[13] X. J. Li, Y. Y. Cui, and Z. H. Bai, "Model of plate-out oil film thickness on strip surface of direct application system in double cold rolling and its influence factors," Journal of Plasticity Engineering, vol. 25, no. 4, pp. 285-290, 2018.

[14] J. L. Sun, Lubrication Theory, Technology and Application of Rolling Process, Metallurgical Industry Press, Beijing, China, 2010.

[15] S. Z. Wen, P. Huang, Y. Tian et al., Principle of Tribology, Tsinghua University Press, Beijing, China, 2018. 